\title{
Monitoring and characterization of compost obtained of sludge of ultra-processed food industry by conventional and spectroscopic analyses
}

\section{Monitoramento e caracterização de composto obtido de lodo de indústria de alimentos ultra processados por análises convencionais e espectroscópicas}

\author{
Cleber Pinto da Silva ${ }^{1}$; Bruna Pompermayer Meotti De Almeida ${ }^{2}$; \\ Sandro Xavier de Campos ${ }^{3}$
}

\begin{abstract}
Several studies of potentially toxic residues have already been documented in the literature. However, studies focused on treatment of sludge of effluent treatment plant (ETP) from the ultra-processed food industry have been very little addressed. Sludge composting of the ultra-processed food industry in piles was monitored by conventional techniques (temperature, humidity, $\mathrm{pH}$ and seed germination index) and spectroscopic analyzes (UV-Vis, FTIR and FAAS). The experiments were carried out with two piles from different sludge combinations from the ultra-processed food industry associated with garden pruning or sawdust. The pile were prepared approximately $1 \mathrm{mx} 1 \mathrm{mx} 1 \mathrm{~m}$ in size and were manually revolved once a week for up to 180 days. The piles presented thermophilic phase for approximately two weeks. After 90 days, the seed germination index (SGI) reached values of 62.5 for pile 1 and $87.5 \%$ for pile 2 . The spectroscopic analysis indicated the occurrence of degradation of aliphatic/polysaccharide structures and the increase of oxygenated functional groups. The concentration of the metallic ions: $\mathrm{Ni}, \mathrm{Cd}, \mathrm{Cr}, \mathrm{Pb}, \mathrm{Cu}, \mathrm{Mn}$ and $\mathrm{Zn}$ in the compounds obtained from the two piles was lower than the values established for use as soil conditioner or organic fertilizer. The composting process in piles was efficient to degrade the sludge of the ultra-processed food industry, associated with garden pruning or sawing, resulting in stabilized compounds.
\end{abstract}

Keywords: Ultra-processed foods. Metallic ions. Organic fertilize.

\section{Resumo}

\begin{abstract}
Vários estudos de resíduos potencialmente tóxicos já foram documentados na literatura. No entanto, estudos voltados para o tratamento do lodo de efluentes de estações de tratamento de efluentes (ETP) da indústria de alimentos ultra processados têm sido pouco abordados. A compostagem de lodo da indústria de alimentos ultra processados em pilhas foi monitorada por técnicas convencionais (temperatura, umidade, $\mathrm{pH}$ e índice de germinação de sementes) e análises espectroscópicas (UV-Vis, FTIR e FAAS). Os experimentos foram conduzidos com duas pilhas de diferentes combinações de lodo da indústria alimentícia ultra processada, associada à poda de jardim ou serragem. As pilhas foram preparadas com aproximadamente $1 \mathrm{~m}$ x $1 \mathrm{~m}$ x $1 \mathrm{~m}$ de tamanho e foram revolvidas manualmente uma vez por semana por até 180 dias. As pilhas apresentaram fase termofílica por aproximadamente duas semanas. Após 90 dias, o índice de germinação de sementes (IGS) atingiu 62,5 para a pilha 1 e $87,5 \%$ para a pilha 2 . A análise espectroscópica indicou a ocorrência de degradação de estruturas alifáticas/polissacarídicas e o aumento de grupos funcionais oxigenados. A concentração dos íons metálicos $\mathrm{Ni}, \mathrm{Cd}, \mathrm{Cr}, \mathrm{Pb}, \mathrm{Cu}, \mathrm{Mn}$ e $\mathrm{Zn}$ nos compostos obtidos nas duas pilhas foi menor que os valores estabelecidos para uso como condicionador de solo ou adubo orgânico. O processo de compostagem em pilhas foi eficiente para degradar o lodo da indústria de alimentos ultra processados, associado à poda de jardim ou serragem, resultando em compostos estabilizados.
\end{abstract}

Palavras-chave: Alimentos ultra processados. Íons metálicos. Fertilizante orgânico.

\footnotetext{
${ }^{1}$ Doutorando em Química, UEPG, Ponta Grossa, Pr, Brasil; E-mail: qaasuepgcleber@ gmail.com

${ }^{2}$ Me. em Química, UEPG, Ponta Grossa, Pr, Brasil; E-mail: b_meotti@ hotmail.com

${ }^{3}$ Dr. Prof. Dpto de Química, UEPG, Ponta Grossa, Pr, Brasil; E-mail: campos@uepg.br
} 


\section{Introduction}

Ultra-processed foods are products ready for consumption, produced from substances extracted from food or synthesized from synthetic organic materials (COSTA LOUZADA et al., 2015). For the production of this type food, the industry uses high amounts of water daily, producing large volumes of effluent and sludge as the final reject of the process (AWASTHI et al., 2016; VAN DEN HENDE et al., 2016). The sludge from effluent treatment plants (ETP) in food industries has different characteristics, including contaminants from raw materials processed, chemicals and waste from technological additives used in their operations (QASIM; MANE, 2013).

However, the direct disposal of this material in the environment without proper treatment represents a problem for the society, increasing the volume of landfills, contaminating the soil and bodies of water, emitting greenhouse gases, among others (AWASTHI et al., 2016; WANG et al., 2016). The decomposition by composting has already been studied using kitchen-waste (YANG et al., 2015), animal feces (FIALHO et al., 2010; SALEEM et al., 2018; XU; LI, 2017), sludge from breweries (STOCKS; BARKER; GUY, 2002) and urban ETP sludge (DZULKURNAIN et al., 2017; KUMAR AWASTHI et al., 2017; MENG et al., 2016). However, research focused on the treatment of ETP sludge from the ultra- processed food industry is scarce.

Composting is a technology capable of obtaining a stabilized, nutrient-rich compound after the treatment of potentially toxic materials, which can benefit agricultural practices and reduce inorganic fertilizer applications (FIALHO et al., 2010; HE et al., 2011). Composting processes are usually characterized by the decomposition of materials that act as nitrogen sources (domestic organic waste) together with structural materials (plant pruning and sawdust) as a carbon source (MORETTI et al., 2016). Several criteria and parameters were proposed and adopted to test the maturity and stability of the compound (BERNAL; ALBURQUERQUE; MORAL, 2009). Conventional controls (temperature, moisture, $\mathrm{pH}$, $\mathrm{C} / \mathrm{N}$ and germination index) and spectroscopic analyses (Uv/Vis, FTIR and FAAS) are efficient ways to monitor the stabilization and toxicity of composted material (GUO et al., 2012; MCWHIRT et al., 2012; USMAN et al., 2012).

The stabilized or matured material must have phytotoxicity index above $50 \%, \mathrm{pH}$ close to neutrality and reduction of C/N ratio (CHIKAE et al., 2006; SHAFFER, 2010; TIQUIA et al., 1997). In addition, the increase in absorptions between specific wavelengths are proportional to the number of condensed rings. The decrease in the ratio between absorption intensities of 250/365 nm indicates the degradation of simpler molecules. The wavelength ratio $465 / 665 \mathrm{~nm}$ is inversely proportional to the degree of condensation of the unsaturated structures, so that a high ratio of this index indicates a low degree of condensation of carbon-carbon unsaturation and the presence of various olefinic structures (CAMPOS; RESSETI; ZITTEL, 2014). Thus, it is expected that for a stabilized compound, the values of the 250/365 $\mathrm{nm}$ ratio decrease and the values of the $465 / 665 \mathrm{~nm}$ ratio increase.

The purpose of this study was to evaluate the efficiency of the composting process, using ETP sludge from the ultra-processed food industry with different structuring materials, by employing conventional and spectroscopic techniques.

\section{Materials and Methods}

\section{Experiments}

Two piles ( $1 \mathrm{~m}$ wide, $1 \mathrm{~m}$ long and $1 \mathrm{~m}$ high) were mounted. The piles were assembled containing the following materials: Garden Pruning (GP), Sawdust (Sa) and ETP sludge from the ultra-processed food industry. The distribution of the residues in the piles and the characteristics of the materials are presented in Table 1.

Table 1 - Combination of waste and characteristics of the materials in the piles. (Mean $\pm \mathrm{Sd}$; $\mathrm{n} 3$ ).

\begin{tabular}{lccc}
\hline & GP & Sa & Sludge \\
\hline Pile 1 $(\mathrm{kg})$ & 20 & 0 & 95 \\
Pile 2 $(\mathrm{kg})$ & 0 & 43 & 106 \\
$\mathrm{pH}$ & 7.9 & 5.6 & 7.8 \\
$\mathrm{MC}(\%)$ & 5.3 & 0.6 & 91.1 \\
$\mathrm{Cu}\left(\mathrm{mg} \mathrm{kg}^{-1}\right)$ & $2.5 \pm 0.4$ & $7.1 \pm 0.8$ & $19.6 \pm 1.0$ \\
$\mathrm{Mn}\left(\mathrm{mg} \mathrm{kg}^{-1}\right)$ & $1.5 \pm 0.2$ & $51.3 \pm 6.4$ & $246.4 \pm 2.8$ \\
$\mathrm{Ni}\left(\mathrm{mg} \mathrm{kg}^{-1}\right)$ & $<\mathrm{LQ}$ & $<\mathrm{LQ}$ & $32.6 \pm 3.3$ \\
$\mathrm{Cd}\left(\mathrm{mg} \mathrm{kg}^{-1}\right)$ & $<\mathrm{LQ}$ & $<\mathrm{LQ}$ & $3.3 \pm 0.12$ \\
$\mathrm{~Pb}\left(\mathrm{mg} \mathrm{kg}^{-1}\right)$ & $<\mathrm{LQ}$ & $<\mathrm{LQ}$ & $8.4 \pm 1.3$ \\
$\mathrm{Cr}\left(\mathrm{mg} \mathrm{kg}^{-1}\right)$ & $<\mathrm{LQ}$ & $<\mathrm{LQ}$ & $7.9 \pm 1.1$ \\
$\mathrm{Zn}\left(\mathrm{mg} \mathrm{kg}^{-1}\right)$ & $54.2 \pm 6.6$ & $17.2 \pm 1.6$ & $384.0 \pm 15.2$ \\
\hline
\end{tabular}

GP: Garden Pruning; Sa: Sawdust; Moisture Content: MC; LQ: Limit Quantification.

Source: The authors. 
The compost was prepared with two different types of organic waste mixtures according to the quantification presented in Table 1. The initial $\mathrm{C} / \mathrm{N}$ ratios were calculated from the $\mathrm{C}$ and $\mathrm{N}$ contents and taking into account the equation proposed by Caricasole et al. (2011).

Those amounts were used to ensure $\mathrm{C} / \mathrm{N}$ ratio of about 46 in pile 1 and 49 in pile 2. Bulking agents were mixed with the substrates to ensure suitable aeration. In pile 1 , was added GP, while in pile 2 was added Sa. The piles were prepared in a shed to avoid excess moisture of rain and were manually revolved once a week until the 180 days. When the mixture obtained moisture below $40 \%$, water was added during the revolving.

Samples were collected from seven random locations distributed on the inside and on the surface of the piles, being homogenized until approximately $1.0 \mathrm{~kg}$ of sample was obtained for each pile and time. Samples for analysis of $\mathrm{C} / \mathrm{N}$, seed germination index, metal ions, Uv-vis and FTIR were ground in Gral and standardized in 18 mesh sieve. The other analyzes were performed with in - natura samples. The collections and the composting process were followed up for 180 days. All analyzes were performed in triplicates for each composting time.

\section{Moisture, Temperature, $p H, C / N$ ratio}

In order to control the moisture, readings of the mixtures in the piles were carried out fortnightly. A digital thermo hygrometer was used for this analysis. The temperature was verified daily in the pile with a mercury thermometer. The $\mathrm{pH}$ value was determined fortnightly, according proposed by Fialho et al. (2010). The elemental chemical analysis to determine the $\mathrm{C} / \mathrm{N}$ ratio was a performed the elemental analyzer fisions CHNS-O apparatus.

\section{Seed germination index (SGI)}

To evaluate the phytotoxicity, $20 \mathrm{~g}$ of dry weight compost were extracted with $200 \mathrm{ml}$ of distilled water stirred for $1 \mathrm{~h}$ and then centrifuged at $10.000 \mathrm{rpm}$. Then $5 \mathrm{ml}$ of the aqueous extract was added in petri dishes containing 10 seeds of Lepidium sativum each. The sets were incubated in a dark environment at $25^{\circ} \mathrm{C}$ for 5 days. Control tests were performed, replacing the aqueous extract with distilled water. The SGI was calculated according to the equation proposed by Tiquia, Tam and Hodgkiss (1997).

SGI $\%=\frac{\text { seed germination-root length of treatment }}{\text { seed germination-root length of control }}$

\section{$U v$-Vis spectroscopy}

For the Uv-Vis analyses, portions containing $0.02 \mathrm{~g}$ of the samples were dissolved in $10 \mathrm{ml}$ of a $0.05 \mathrm{~mol} \mathrm{~L}^{-1}$ sodium bicarbonate solution, then the absorption readings were carried out using the apparatus varian Cary 50 bio. Then, the ratios between the absorbance at $250 \mathrm{~nm}$ and 365 $\mathrm{nm}\left(\mathrm{E}_{2} / \mathrm{E}_{3}\right), 465 \mathrm{~nm}$ and $650 \mathrm{~nm}\left(\mathrm{E}_{4} / \mathrm{E}_{6}\right)$ and aromaticity (52.5 - $\left.6.78 \quad \mathrm{E}_{2} / \mathrm{E}_{3}\right)$ were determined (PEURAVUORI; PIHLAJA, 1997).

\section{FTIR spectroscopy}

For the FTIR analyses, pellets were prepared by homogenizing $1.0 \mathrm{mg}$ sample with $100 \mathrm{mg}$ of potassium bromide. Then they were inserted into an FTIR spectrometer, brand Shimadzu, model IR prestige 21, and the readings ranged from 400 to $4000 \mathrm{~cm}^{-1}$ with spectral resolution of $4 \mathrm{~cm}^{-1}$ (FIALHO et al., 2010). Then the ratios of the transmittances from wavenumbers 1647/2928, 1647/1417 and $1647 / 1030$ were determined.

\section{Determination of metallic ions}

The samples were submitted to digestion using the method 3050-B (USEPA, 1996). Approximately $0.5 \mathrm{~g}$ sample and $5 \mathrm{ml}$ concentrated nitric acid were added. The samples were digested in digester block for $2 \mathrm{~h}$ at $95 \pm 5^{\circ} \mathrm{C}$

Then, $1.5 \mathrm{ml}$ of hydrogen peroxide $30 \%$ was added, and after another $1 \mathrm{~h}$ of reaction a further $5 \mathrm{ml}$ concentrated hydrochloric acid was added, followed by a further $1 \mathrm{~h}$ digestion. The extracts obtained transferred to $50 \mathrm{ml}$ volumetric flasks and completed with ultrapure water. Reagent blank and triplicate of each sample were evaluated. $\mathrm{Ni}, \mathrm{Cd}$, $\mathrm{Cr}, \mathrm{Pb}, \mathrm{Cu}, \mathrm{Mn}$ and $\mathrm{Zn}$ metallic ions were quantified. The readings were performed in a Varian model 240fs Flame Atomic Absorption Spectrometer (FAAS).

The accuracy of the method was obtained from the reference material of the Institute for Reference Materials and Measurements (IRMM) in Europe and marine sediments of the National Research Council of Canada (NRCC), recovering between 90 and 103\%.

\section{Results and Discussion}

\section{Moisture, Temperature, $\mathrm{pH}, \mathrm{C} / \mathrm{N}$ ratio}

Controlling physic-chemical parameters is important due to the influence on the conditions necessary for decomposition of the materials during composting. Initially, the moisture content for pile 1 was $50 \%$ and for pile 2 it 
was $55 \%$. For proper development of microbial activity to occur, it is necessary that the initial compound has between 40 and $70 \%$ moisture (EPSTEIN, 2011; KHALID et al., 2011). Thus, Figure 1 presents the temperature values obtained throughout the composting time.

Figure 1 - Temperature variation at the in piles in 180 days

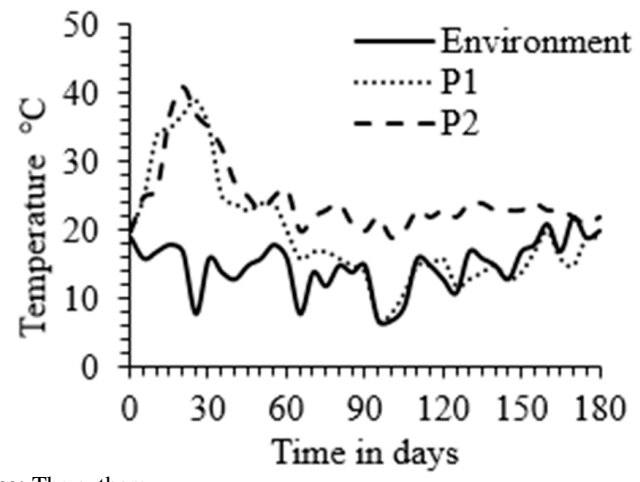

Source: The authors.

Pile 1 showed temperatures $>35^{\circ} \mathrm{C}$ for a period of 15 days, with a peak of 2 days at $39^{\circ} \mathrm{C}$. For pile 2, temperatures $>35^{\circ} \mathrm{C}$ were observed for 13 days with a peak of 3 days at $41{ }^{\circ} \mathrm{C}$. From the third week, the temperatures of the piles declined rapidly to environmental temperature, showing a decrease in microbial activity. The piles reached the thermophilic phase characterized by temperatures in the range of 35 to $65^{\circ} \mathrm{C}$, indicating increase in microbial activity (INSAM; FRANKE-WHITTLE; GOBERNA, 2010; POLPRASERT; KOOTTATEP, 2017). The thermophilic phase was affected by the decrease in the ambient temperature (Figure 1), due to the loss of heat, which did not allow the composting process to reach higher temperature values. The $\mathrm{pH}$ values varied in the range of 6.7 to 7.5 , indicating that the composting occurred efficiently according to the ideal values of 5.5 to 8.0 (PIOTROWSKA-CYPLIK et $a l ., 2009)$. In 90 days of the process the ratio $\mathrm{C} / \mathrm{N}$ for pile 1 was 10.5 , while for pile 2 it was 16.7 . Final $\mathrm{C} / \mathrm{N}$ ratio low values indicate possible material stabilization and low microbial activity (PROVENZANO et al., 2001). According to Bustamante et al., (2008) C/N ratios lower than 20 indicate an optimal degree of maturation. This indicates that the composted materials were stabilized.

\section{Seed germination index (SGI)}

The germination index (SGI) is used to evaluate the toxicity and stabilization of composted material. For a compound to be considered non-phytotoxic, it must present a germination index $\geq 50 \%$ (CHIKAE et al., 2006). After 90 days of composting, the SGI value for pile 1 was $62.5 \%$, while for pile 2 it was $87.5 \%$. Studies indicate that ETP sludge from the industry contains large concentrations of metallic ions and potentially toxic organic contaminants (FANG et al., 2017). The SGI values of the piles demonstrated that the compounds at 90 days are not phytotoxic, even employing ETP sludge from the ultra-processed food industry as feedstock.

\section{Uv-Vis spectroscopy}

The results obtained by the Uv-Vis analysis were used to calculate the $\mathrm{E}_{2} / \mathrm{E}_{3}, \mathrm{E}_{4} / \mathrm{E}_{6}$ and total aromaticity ratios, and are presented in Figure 2.

Figure 2 - Ratio Uv -Vis during composting in 180 days

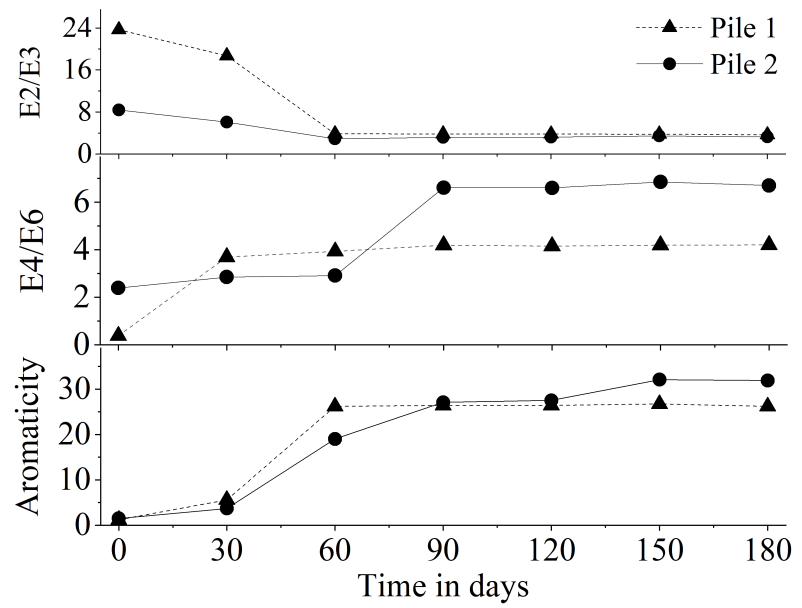

Source: The authors.

The reduction in $E_{2} / E_{3}$ ratio for the two piles was observed in Figure 2. Between 60 and 150 days it was verified that $E_{2} / E_{3}$ ratio presented stability, for pile 1 the mean ratio was $3.83 \pm 0.02$, while for pile 2 the mean was $3.55 \pm 0.91$. There was, therefore, degradation of aliphatic molecules, mainly in the first 60 days of the process (FIALHO et al., 2010). Significant increase in total aromaticity values during the first 60 days of composting was observed, which is related to the biological activity of organic matter degradation and stabilization (FIALHO et al., 2010; PEURAVUORI; PIHLAJA, 1997). The $\mathrm{E}_{4} / \mathrm{E}_{6}$ ratio increased during the composting period, and the highest values observed were for pile 2 after 90 days, stabilizing at the end of the process. Studies indicate that the increase in $\mathrm{E}_{4} / \mathrm{E}_{6}$ ratio during sludge composting of ETP, is associated with the increase in oxygenated functional groups of humic acids (KIM et al., 2008; PAJĄCZKOWSKA et al., 2003). 
The characteristics of the products after 90 days of the beginning of the process pointed to a stabilized material, which when applied to the soil can increase the amount of organic matter, reducing the need to apply inorganic fertilizers.

\section{FTIR spectroscopy}

Figure 3 shows the ratios of wavenumbers 1647/2928, 1647/1406 and 1647/1030 for FTIR analyses.

Figure 3 - FTIR ratio during composting in 180 days

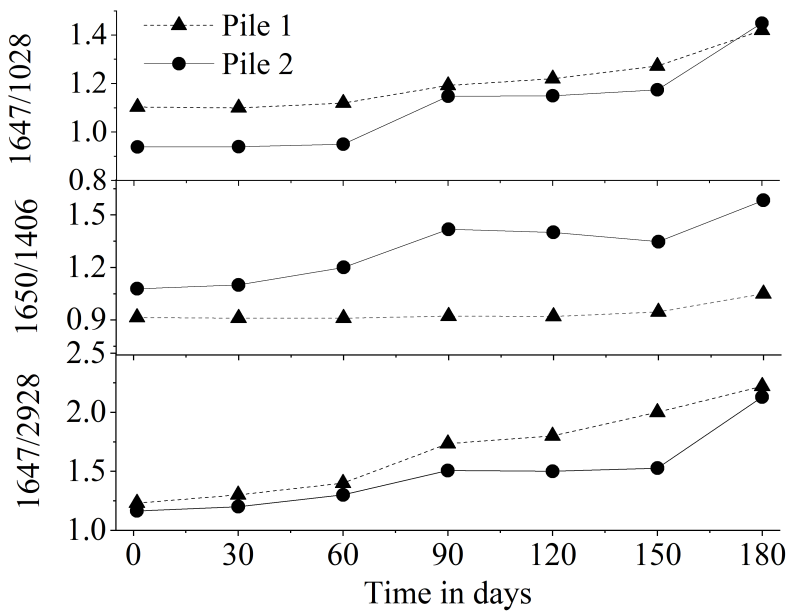

Source: The authors.

The ratio 1647/2928 demonstrates the relationship between the aromatic/aliphatic carbons. For this ratio, pile 1 was seen to increase from 1.23 to 2.22 , while pile 2 increased from 1.16 to 2.13 during the controlled composting period. According to Sen Chandra, (2007) this result is due to the formation of condensed polymers from the degradation of aliphatic structures, which is in agreement with the $E_{2} / E_{3}$ ratio and total aromaticity. The $1647 / 1417$ ratio demonstrates the ratio of aromatic/carboxylic carbons, which increased from 0.91 to 1.5 for pile 1 , while for pile 2 the increase was from 1.07 to 1.58 . According to He et al., (2011), during the composting process the increase in aromatic and carboxylic carbons occurs. From the analysis of Figure 3, a significant reduction of the $1647 / 1417$ ratio in relation to the $1647 / 2928$ ratio can be observed, which may indicate higher formation of carboxylic acids, which is in agreement with the $\mathrm{E}_{4} / \mathrm{E}_{6}$ ratio previously found. The 1647/1030 ratio demonstrates the relationship between aromatic carbons/polysaccharides and Figure 3 shows the increase from 1.10 to 1.42 in pile 1 and from 0.93 to 1.45 in pile 2 . This increase was possibly caused by the degradation of polysaccharides metabolized by microorganisms during compost- ing, producing new aromatic substances (DROUSSI et al., 2009; HE, XIAO-SONG et al., 2012; SONG et al., 2015).

Spectroscopic results indicated degradation of aliphatic compounds and polysaccharides during the composting process.

\section{Determination of metallic ions}

The concentrations of $\mathrm{Ni}, \mathrm{Cd}, \mathrm{Cr}, \mathrm{Pb}, \mathrm{Cu}, \mathrm{Mn}$ and $\mathrm{Zn}$ metallic ions were evaluated in the product of 120 days and results are presented in Table 2 .

Table 2 - Concentration of metallic ions in the two piles in the period of 120 days and maximum limits allowed. (Mean \pm Sd; n3).

\begin{tabular}{ccccc}
\hline & Pile 1 & Pile 2 & $\begin{array}{c}\text { USDA, } \\
(1980)\end{array}$ & $\begin{array}{c}\text { CCME, } \\
(2005)\end{array}$ \\
\hline $\mathrm{Ni}$ & $<\mathrm{LQ}$ & $<\mathrm{LQ}$ & 200 & 62 \\
$\mathrm{Cd}$ & $<\mathrm{LQ}$ & $<\mathrm{LQ}$ & 10 & 3 \\
$\mathrm{Cr}$ & $<\mathrm{LQ}$ & $<\mathrm{LQ}$ & 1000 & 210 \\
$\mathrm{~Pb}$ & $3.55 \pm 0.43$ & $5.248 \pm 0.23$ & 250 & 150 \\
$\mathrm{Cu}$ & $22.41 \pm 0.02$ & $21.64 \pm 0.06$ & 1000 & 400 \\
$\mathrm{Mn}$ & $135.48 \pm 0.07$ & $224.93 \pm 0.11$ & - & - \\
$\mathrm{Zn}$ & $458.58 \pm 0.05$ & $261.62 \pm 0.02$ & 2500 & 700 \\
\hline
\end{tabular}

Concentration in $\mathrm{mg} \mathrm{kg}^{-1}$; LQ: limit quantification.

Source: The authors.

The metallic ions $\mathrm{Ni}, \mathrm{Cd}$ and $\mathrm{Cr}$ were below the limit of quantification of the equipment $0.157,0.29$ and 0.53 $\mathrm{mg} \mathrm{kg}{ }^{-1}$ respectively. The total concentration of $\mathrm{Ni}, \mathrm{Cd}$, $\mathrm{Cr}, \mathrm{Pb}, \mathrm{Cu}, \mathrm{Mn}$ and $\mathrm{Zn}$ metallic ions was below the control values established by the U.S department of agriculture and the Canadian Council of Ministers of the Environment for the use organic compounds in agriculture (CCME, 2005; USDA, 1980), indicating that the compound can be used according to these parameters. The concentrations of these metallic ions in biosolids are regulated by the characteristics of the composted material and the type of process used during the treatment (WUANA; OKIEIMEN, 2014). Although previous studies (AWASTHI et al., 2016; KULIKOWSKA; GUSIATIN, 2015; MORETTI et al., 2016) concluded that ETP sludge from the industry are sources of high concentrations of potentially toxic metals, the composted blends of ETP from the ultra-processed food industry obtained values below the limit established for the production of organic fertilizer. Therefore, it can be used according to international control standards. 


\section{Conclusions}

According to the results of the seed germination index, the final compound did not present phytotoxicity. The $\mathrm{C} / \mathrm{N}$ ratio decreased to levels below 20 within 90 days, indicating stabilization of the compound. Monitoring of variation in Uv-vis and FTIR ratios indicates that the compound reached the degree of stabilization. The metal ion concentrations of the final compound are in accordance with permitted limits for the production of organic fertilizers. Therefore, the compost obtained from the sludge composting of the ultra-processed food industry can be considered as a fertilizer.

\section{References}

AWASTHI, M. K.; PANDEY, A. K.; BUNDELA, P. S.; WONG, J. W. C.; LI, R.; ZHANG, Z. Co-composting of gelatin industry sludge combined with organic fraction of municipal solid waste and poultry waste employing zeolite mixed with enriched nitrifying bacterial consortium. Bioresource Technology, Barking, v. 213, p. 181-189, 1 ago. 2016.

BERNAL, M. P.; ALBURQUERQUE, J. A.; MORAL, R. Composting of animal manures and chemical criteria for compost maturity assessment. a review. Bioresource Technology, Barking, v. 100, n. 22, p. 5444-5453, 1 nov. 2009.

BUSTAMANTE, M. A.; PAREDES, C.; MARHUENDAEGEA, F. C.; PÉREZ-ESPINOSA, A.; BERNAL, M. P.; MORAL, R. Co-composting of distillery wastes with animal manures: Carbon and nitrogen transformations in the evaluation of compost stability. Chemosphere, Oxford, v. 72, n. 4, p. 551-557, 2008.

CAMPOS, S. X.; RESSETI, R. R.; ZITTEL, R. Monitoring and characterization of compost obtained from household waste and pine sawdust in a facultative reactor by conventional and spectroscopic analyses. Waste Management \& Research, v. 32, n. 12, p. 1186-1191, 2014.

CARICASOLE, P.; PROVENZANO, M. R.; HATCHER, P. G.; SENESI, N., Evolution of organic matter during composting of different organic wastes assessed by cpmas 13C NMR spectroscopy. Waste Management, v. 31, n. 3, p. 411-415, 2011.

CCME - Canadian Council of Ministers of the Environment. Guidelines for Compost Quality. [Canadá: CCME], 2005.
CHIKAE, M.; IKEDA, R.; KERMAN, K.; MORITA, Y.; TAMIYA, E. Estimation of maturity of compost from food wastes and agro-residues by multiple regression analysis. Bioresource Technology, Barking, v. 97, n. 16, p. 1979-1985, nov. 2006.

COSTA LOUZADA, M. L.; MARTINS, A. P.; CANELLA, D. S.; BARALDI, L. G.; LEVY, R. B.; CLARO, R. M.; MOUBARAC, J. C.; CANNON, G.; MONTEIRO, C. A. Ultra-processed foods and the nutritional dietary profile in Brazil. Revista de Saúde Pública, São Paulo, v. 49, 2015.

DROUSSI, Z.; D'ORAZIO, V.; HAFIDI, M.; OUATMANE, A. Elemental and spectroscopic characterization of humic-acid-like compounds during composting of olive mill by-products. Journal of Hazardous Materials, Amsterdam, v. 163, n. 2/3, p. 1289-1297, 2009.

DZULKURNAIN, Z. ;HASSAN, M. A.; ZAKARIA, M. R.; WAHAB, P. E. M.; HASAN, M. Y.; SHIRAI, Y. Cocomposting of Municipal Sewage Sludge and Landscaping Waste: A Pilot Scale Study. Waste and Biomass Valorization, v. 8, n. 3, p. 695-705, abr. 2017.

EPSTEIN, E. Industrial composting: environmental engineering and facilities management. Boca Raton: CRC Press, 2011.

FANG, B.; GUO, J.; LI, F.; GIESY, J. P.; WANG, L.; SHI, W. Bioassay directed identification of toxicants in sludge and related reused materials from industrial wastewater treatment plants in the Yangtze River Delta. Chemosphere, Oxford, v. 168, p. 191-198, fev. 2017.

FIALHO, L. L.; LOPES, S. W. T.; MILORI, D. M.; SIMÕES, M. L.; MARTIN-NETO, L. Characterization of organic matter from composting of different residues by physicochemical and spectroscopic methods. Bioresource Technology, Barking, v. 101, n. 6, p. 1927-1934, 2010.

GUO, R.; LI, G.; JIANG, T.; SCHUCHARDT, F. CHEN, T.; ZHAO, Y.; SHEN, Y. Effect of aeration rate, $\mathrm{C} / \mathrm{N}$ ratio and moisture content on the stability and maturity of compost. Bioresource Technology, Barking, v. 112, p. 171-178, maio 2012

HE, X. S.; XI, B. D.; WEI, Z. M.; JIANG, Y. H.; GENG, C. M.; YANG, Y.; YUAN, Y.; LIU, H. L. Physicochemical and spectroscopic characteristics of dissolved organic matter extracted from municipal solid waste (MSW) and their influence on the landfill biological stability. Bioresource Technology, Barking, v. 102, n. 3, p. 2322-2327, 2011. 
HE, X.-S.; XI, B. D.; JIANG, Y. H.; LI. M. X.; YU, H. B.; AN, D.; YANG, Y.; LIU, H. L. Elemental and spectroscopic methods with chemometric analysis for characterizing composition and transformation of dissolved organic matter during chicken manure composting. Environmental Technology, London, v. 33, n. 17, p. 2033-2039, 2012.

INSAM, H.; FRANKE-WHITTLE, I.; GOBERNA, M. Microbes in aerobic and anaerobic waste treatment. In: INSAM, H.; FRANKE-WHITTLE, I.; GOBERNA, M. (ed.). Microbes at work: from wastes to resources. Heidelberg: Springer Verlag, 2010. p. 1-34.

KHALID, A.; ARSHAD, M.; ANJUM, M.; MAHMOOD,T.; DAWSON, L. The anaerobic digestion of solid organic waste. Waste Management, Elmsford, v. 31, n. 8 , p. 1737-1744, 2011.

KIM, J. D.; PARK, J. S.; IN, B. H.; KIM, D.; NAMKOONG, W. Evaluation of pilot-scale in-vessel composting for food waste treatment. Journal of Hazardous Materials, Amsterdam, v. 154, n. 1/3, p. 272-277, 2008.

KULIKOWSKA, D.; GUSIATIN, Z. M. Sewage sludge composting in a two-stage system: carbon and nitrogen transformations and potential ecological risk assessment. Waste management, New York, v. 38, n. 1, p. 312-320, 2015.

KUMAR AWASTHI, M.; WANG, M.; PANDEY, A.; CHEN, H.; KUMAR AWASTHI, S.; WANG, Q.; REN, X.; HUSSAIN LAHORI, A.; LI, D. S.; LI, R.; ZHANG, Z Heterogeneity of zeolite combined with biochar properties as a function of sewage sludge composting and production of nutrient-rich compost. Waste Management, New York, v. 68, p. $760-773,2017$.

MCWHIRT, A. L.; WEINDORF, D. C.; CHAKRABORTY, S.; LI, B. Visible near infrared diffuse reflectance spectroscopy (VisNIR DRS) for rapid measurement of organic matter in compost. Waste Management and Research, London, v. 30, n. 10, p. 1049-1058, 2012.

MENG, L.; LI, W.; ZHANG, S.; WU, C.; WANG, K. Effects of sucrose amendment on ammonia assimilation during sewage sludge composting. Bioresource Technology, Barking, v. 210, p. 160-166, 2016.
MORETTI, S. M. L.; BERTONCINI, E. I.; VITTI, A. C.; AllEONI, L. R.; ABREU-JUNIOR, C. H. Concentration of $\mathrm{Cu}, \mathrm{Zn}, \mathrm{Cr}, \mathrm{Ni}, \mathrm{Cd}$, and $\mathrm{Pb}$ in soil, sugarcane leaf and juice: residual effect of sewage sludge and organic compost application. Environmental Monitoring and Assessment, Dordrecht, v. 188, n. 3, p. 163, 2016.

PAJĄCZKOWSKA, J.; SULKOWSKA, A.; SULKOWSKI, W. W.; JEDRZEJCZYK, M. Spectroscopic study of the humification process during sewage sludge treatment. Journal of Molecular Structure, Amsterdam, v. 651, p. 141-149, 2003.

PEURAVUORI, J.; PIHLAJA, K. Molecular size distribution and spectroscopic properties of aquatic humic substances. Analytica Chimica Acta, Amsterdam, v. 337, n. 2, p. 133-149, jan. 1997.

PIOTROWSKA-CYPLIK, A.; OLEJNIK, A.; CYPLIK, P.; DACH, J.; CZARNECKI, Z. The kinetics of nicotine degradation, enzyme activities and genotoxic potential in the characterization of tobacco waste composting. Bioresource Technology, Barking, v. 100, n. 21, p. 5037-5044, 2009.

POLPRASERT, Chongrak; KOOTTATEP, Thammarat. Organic waste recycling: technology, management and sustainability - 4th edition. London: IWA Publishing, 2017.

PROVENZANO, M. R.; OLIVEIRA, S. C.; SILVA, M. R.; SENESI, N. Assessment of maturity degree of composts from domestic solid wastes by fluorescence and Fourier transform infrared spectroscopies. Journal of Agricultural and Food Chemistry, Washington, v. 49, n. 12, p. 5874-5879, 2001.

QASIM, W.; MANE, A. V. Characterization and treatment of selected food industrial effluents by coagulation and adsorption techniques. Water Resources and Industry, [Amsterdam], v. 4, p. 1-12, 2013.

SALEEM, A.; FAREED, I.; IRSHAD, M.; MAHMOOD,Q.; ENEJI, A. E.; SHAHZAD, M. Transformations of phosphorus and other plant nutrients in poultry litter composted with sugarcane and cabbage wastes. Compost Science and Utilization, Emmaus, PA, v. 26, n. 2, p. 114-127, 2018. 
SEN, B.; CHANDRA, T. S. Chemolytic and solid-state spectroscopic evaluation of organic matter transformation during vermicomposting of sugar industry wastes. Bioresource Technology, Barking, v. 98, n. 8, p. 1680-1683, 2007.

SHAFFER, B. Curing compost: An antidote for thermal processing. ACRES, v. 40, n. 11, 2010

SONG, C.; LI, M.; XI, B.; WEI, Z.; ZHAO, Y.; JIA, X.; QI, H.; ZHU, C. Characterisation of dissolved organic matter extracted from the bio-oxidative phase of co-composting of biogas residues and livestock manure using spectroscopic techniques. International Biodeterioration and Biodegradation, Barking, v. 103, p. 38-50, 2015 .

STOCKS, C.; BARKER, A. J.; GUY, S. The composting of brewery sludge. Journal of the Institute of Brewing, London, v. 108, n. 4, p. 452-458, 2002.

TIQUIA, S. M.; TAM, N. F. Y.; HODGKISS, I. J. Effects of composting on phytotoxicity of spent pig-manure sawdust litter. Environmental Pollution, Barking, v. 93, n. 3, p. 249-256, 1997.

USDA - United States Department of Agriculture. Report and recommendation on organic farming. [Beltsville: USDA], 1980.

USEPA. United States Environmental Protection Agency.Acid digestion of sendiments, sludges and soils: method 3050-B. [Washington: USEPA], 1996.

USMAN, K.; KHAN, S.; GHULAM, S.; KHAN, M.; KHAN, N.; KHAN, M.; KHALIL, S. Sewage sludge: an important biological resource for sustainable agriculture and its environmental implications. American Journal of Plant Sciences, [Irvine, Calif.], v. 3, p. 1708-1721, 2012.
VAN DEN HENDE, S.; BEELEN, V.; JULIEN, L.; LEFOULON, A.; VANHOUCKE, T.; COOLSAET, C.; SONNENHOLZNER, S.; VERVAEREN, H.; ROUSSEAU, D. P. Technical potential of microalgal bacterial floc raceway ponds treating food-industry effluents while producing microalgal bacterial biomass: an outdoor pilot-scale study. Bioresource Technology, Barking, v. 218, p. 969-979, jul. 2016.

WANG, Q.; LI, R.; CAI, H.; AWASTHI, M. K.; ZHANG, Z.; WANG, J. J.; ALI, A.; AMANULLAH, M. Improving pig manure composting efficiency employing Cabentonite. Ecological Engineering, Amsterdam, v. 87, p. 157-161, 2016.

WUANA, R.; OKIEIMEN, F. Heavy metals in contaminated soils. In: ASRARI, E. (ed.). Heavy metal contamination of water and soil. Oakville: Apple Academic Press, 2014. p. 1-50.

XU, P.; LI, J. Effects of microbial inoculant on physical and chemical properties in pig manure composting. Compost Science and Utilization, Emmaus, v. 25, p. S37-S42, dec. 2017.

YANG, Y. Q.; Chen, Z. X.; Zhang, X. Q.; Hu, L. F.; Shen, D. S.; Long, Y. Y. Effects of added polyacrylamide on changes in water states during the composting of kitchen waste. Environmental Science and Pollution Research, Landsberg, v. 22, n. 3, p. 2295-2302, fev. 2015. 